\title{
Correction to: Implementing the New Urban Agenda: the central role of public space
}

\author{
Michael W. Mehaffy ${ }^{1} \cdot$ Peter Elmlund $^{2} \cdot$ Kyle Farrell $^{1}$
}

Published online: 29 March 2019

(c) Springer Nature Limited 2019

\section{Correction to: URBAN DESIGN International https://doi.org/10.1057/s41289-018-0063-2}

In the second paragraph in the second column on page 2 beginning "1. How important are public spaces as engines of human well-being, economic development and social justice, and what are the threats to them, especially from private interests?" the following sentence has been removed:

"Setha Low also points to a worrisome diminution of the capacity of public spaces to promote social justice and diversity, replaced by a "politics of exclusion"."

On page 3 of the final sentence of the first paragraph "Ali Madanipour and Setha Low again warn of the danger of unequal access when private sector actors have increasing control over public spaces" has been replaced by "Ali
Madanipour again warns of the danger of unequal access when private sector actors have increasing control over public spaces".

Publisher's Note Springer Nature remains neutral with regard to jurisdictional claims in published maps and institutional affiliations.

The online version of the original article can be found under doi: https://doi.org/10.1057/s41289-018-0063-2.

Michael W. Mehaffy

michael.mehaffy@gmail.com

1 Centre for the Future of Places, KTH Royal Institute of Technology, Stockholm, Sweden

2 Department of Urban Planning and Environment, KTH Royal Institute of Technology, Stockholm, Sweden 